\title{
A PROSPECTIVE STUDY ON ROLE OF SCLEROTHERAPY IN MANAGEMENT OF FIRST AND SECOND DEGREE HAEMORRHOIDS
}

\author{
Vivek Ambedkar ${ }^{1}$, Abhilash Singh ${ }^{2}$, A.P.S. Gaharwar ${ }^{3}$, Vikas Singh ${ }^{4}$, Dheer Singh Rana ${ }^{5}$ \\ ${ }^{1}$ Senior Resident, Department of Surgery, GTB. Hospital and UCMS, Delhi. \\ ${ }^{2}$ Senior Resident, Department of Surgery, GTB. Hospital and UCMS, Delhi. \\ ${ }_{3}^{3}$ Medical Superintendent, Professor and HOD, Department of Surgery, Government Shyam Shah Medical College, Rewa. \\ ${ }^{4}$ Senior Resident, Department of Urology, SMS Medical College, Jaipur. \\ 5 Senior Resident, Department of Surgery, GTB Hospital and UCMS, Delhi.
}

\section{ABSTRACT}

\section{AIM AND OBJECTIVE}

To find out the safety and efficacy of sclerotherapy in management of symptomatic first and second degree haemorrhoids.

\section{PATIENTS AND METHODS}

Total 53 patients of both genders were selected with diagnosis of symptomatic first or second degree haemorrhoids, all of them were subjected for injection sclerotherapy and procedure repeated as per need. Patients were assessed at 1 week, 1 month, 3 months and 6 months thereafter.

\section{RESULTS}

Bleeding stopped in $94.3 \%$ of the patients after treatment at 6 months follow-up with early and smooth recovery without any significant morbidity.

\section{CONCLUSION}

This prospective study concluded sclerotherapy as a safe, easy, cheap and effective method of treatment of first degree and early second degree haemorrhoids devoid of any significant complications.

\section{KEYWORDS}

Haemorrhoids, Sclerotherapy, First Degree Haemorrhoids, Second Degree Haemorrhoids, Rubber Band Ligation, Anorectal Symptoms.

HOW TO CITE THIS ARTICLE: Ambedkar V, Singh A, Gaharwar APS, et al. A prospective study on role of sclerotherapy in management of first and second degree haemorrhoids. J. Evolution Med. Dent. Sci. 2016;5(69):5007-5009, DOI: $10.14260 /$ jemds/2016/1137

\section{INTRODUCTION}

Haemorrhoids are the most prevalent anorectal disorder among adults, and it has been stated that up to half of people may experience problems with haemorrhoids at some point in their lives.1,2 Vascular piles are a part of anal canal continence (left lateral, right anterior and right posterior) and if symptomatic called haemorrhoids. ${ }^{3}$ It is thought that clinical disease develops as a result of dilation and distension of the veins along with weakening of the supporting connective tissue. ${ }^{4}$ In the treatment of first and second degree piles methods like sclerotherapy, infrared coagulation or cryotherapy may be helpful in $90 \%$ patients. 1,5 Sclerotherapy is time-honoured, outpatient procedure that is widely practiced globally to treat haemorrhoids. It started about one and a half century ago and was first advocated in US by Blackwood in 1866. Moreover the procedure is simple, safe, cost effective and painless which can be administered as an outpatient setting. ${ }^{6}$ However, large dose single session sclerotherapy provides only short term benefits in the majority of patients with symptomatic haemorrhoids. ${ }^{7}$ In present study, sclerotherapy has been emerged as safe and

Financial or Other, Competing Interest: None.

Submission 21-07-2016, Peer Review 14-08-2016,

Acceptance 20-08-2016, Published 29-08-2016.

Corresponding Author:

Dr. Abhilash Singh,

\#D-333, Second Floor, Anand Vihar

East Delhi-110092,

Delhi, India.

E-mail:drabhilashsingh03@gmail.com

DOI: $10.14260 /$ jemds/2016/1137 efficacious method of treatment for early internal haemorrhoids.

\section{MATERIAL AND METHODS}

The present prospective study was carried out in Department of Surgery, Govt. Shyam Shah Medical College and associated Sanjay Gandhi Memorial Hospital, Rewa (M.P.).

Total 53 patients were selected with primary diagnosis of first and second degree of internal haemorrhoids, informed written consent was taken and explained about risk and benefits of the procedure. Adequate bowel preparation was ensured by syrup laxative for 2 days as per need.

Sclerosants $5 \%$ Phenol in Almond oil or Sodium Tetradecyl Sulphate was injected in the submucosa of the pedicle of each haemorrhoid under proctoscopic guidance. Maximum three injections were given per session. Patients were re-examined after seven days of injection, followed up on 1 month, 3 months and 6 months subsequently or earlier as per need. Second and third doses of sclerotherapy were administrated after 21 days of interval as per need. All the significant data of history, examination, management and complications were collected and recorded in a preformed data sheet and analysed by Statistical Package of Social Science (SPSS).

\section{RESULTS}

A total of 53 patients were included in the present study, average age in present study was 41 years, half $(49 \%, n=26)$ of the patients were in the age group of $21-40$ years, $87 \%$ $(n=46)$ of the patients were male and most $(73.5 \%, n=39)$ of the patients were vegetarian. 
Distribution of the patients according to clinical presentation revealed bleeding per rectum in all $(100 \%$, $n=53$ ) patients as presenting complaints of early internal haemorrhoids associated with constipation in $60.3 \%(n=32)$ (Table I).

\begin{tabular}{|c|c|c|c|}
\hline $\begin{array}{c}\text { Sl. } \\
\text { No. }\end{array}$ & $\begin{array}{c}\text { Clinical } \\
\text { Presentation }\end{array}$ & $\begin{array}{c}\text { No. of } \\
\text { Patients }\end{array}$ & Percentage \\
\hline 1 & Bleeding Per Rectum & 53 & 100.0 \\
\hline 2 & Constipation & 32 & 60.4 \\
\hline 3 & Mucous Discharge & 09 & 17.0 \\
\hline 4 & Itching & 07 & 13.2 \\
\hline 5 & $\begin{array}{c}\text { Pain during } \\
\text { Defecation }\end{array}$ & 03 & 05.7 \\
\hline 6 & Urgency & 02 & 03.8 \\
\hline \multicolumn{3}{|c|}{ Table I: Distribution of the Patients According } \\
to Clinical Presentation (n=53) \\
\hline
\end{tabular}

Distribution of the patients according to type of haemorrhoids revealed that most $(62.3 \%, n=33)$ of the patients had first-degree haemorrhoids (Table II).

\begin{tabular}{|c|c|c|c|}
\hline $\begin{array}{c}\text { Sl. } \\
\text { No. }\end{array}$ & $\begin{array}{c}\text { Type of } \\
\text { Haemorrhoids }\end{array}$ & $\begin{array}{c}\text { No. of } \\
\text { Patients }\end{array}$ & Percentage \\
\hline 1 & First degree & 31 & 58.5 \\
\hline 2 & Second degree & 22 & 41.5 \\
\hline \multicolumn{3}{|c|}{ Table II: Distribution of the Patients According } \\
to Types of Haemorrhoids (n=53) \\
\hline
\end{tabular}

Distribution of the patients according to response of sclerotherapy revealed that most $(94.3 \%, n=50)$ of the patients got benefit from sclerotherapy, whereas all $(100 \%$, $\mathrm{n}=31$ ) patients with first degree haemorrhoids were relieved (Table III).

\begin{tabular}{|c|c|c|c|c|}
\hline $\begin{array}{c}\text { Type of } \\
\text { Haemorrhoids }\end{array}$ & $\begin{array}{c}\text { No } \\
\text { Change } \\
(\%)\end{array}$ & $\begin{array}{c}\text { Reduced } \\
\text { Bleeding } \\
\text { (\%) }\end{array}$ & $\begin{array}{c}\text { Cured } \\
\mathbf{( \% )}\end{array}$ & $\begin{array}{c}\text { Total } \\
\text { Relieved } \\
\text { (\%) }\end{array}$ \\
\hline $\begin{array}{c}\text { First Degree } \\
\text { (n=31) }\end{array}$ & $00(00)$ & $04(12.9)$ & $27(87.0)$ & $31(100)$ \\
\hline $\begin{array}{c}\text { Second Degree } \\
\text { (n=22) }\end{array}$ & $03(13.6)$ & $07(31.8)$ & $12(54.5)$ & $19(86.3)$ \\
\hline $\begin{array}{c}\text { Total } \\
(\mathrm{n}=53)\end{array}$ & $03(05.7)$ & $11(20.8)$ & $39(73.6)$ & $50(94.3)$ \\
\hline \multicolumn{4}{|c|}{ Table III: Distribution of the Patients According } \\
to Response of Sclerotherapy (n=53)
\end{tabular}

Distribution of the patients according to complications following sclerotherapy revealed mild complications in a few patients (Table IV).

\begin{tabular}{|c|c|c|c|}
\hline $\begin{array}{c}\text { Sl. } \\
\text { No. }\end{array}$ & Complications & $\begin{array}{c}\text { No. of } \\
\text { Patients }\end{array}$ & $\mathbf{\%}$ \\
\hline 1 & $\begin{array}{c}\text { Pain (More than 7 } \\
\text { at VAS Scale) }\end{array}$ & 03 & 05.7 \\
\hline 2 & Haemorrhage & 04 & 07.5 \\
\hline 3 & Retention of Urine & 01 & 01.9 \\
\hline 4 & Prostatitis & 01 & 01.9 \\
\hline 5 & Itching & 01 & 01.9 \\
\hline 6 & Thrombosis & 00 & 00.0 \\
\hline 7 & Vasovagal Shock & 00 & 00.0 \\
\hline 8 & Tenesmus & 00 & 00.0 \\
\hline 9 & Abscess Formation & 00 & 00.0 \\
\hline 10 & Infertility & 00 & 00.0 \\
\hline 11 & Allergic Reactions & 00 & 00.0 \\
\hline \multicolumn{3}{|c|}{ Table IV: Complications following } \\
Sclerotherapy (n=53) \\
\hline
\end{tabular}

\section{DISCUSSION}

Haemorrhoids are one of the most commonly encountered diseases in surgical OPD or Emergency. Abnormal dilatation and distortion of the vascular channels, together with destructive changes in the supporting connective tissue within the anal cushion, is a paramount finding and now considered to be the most important aetiological factor for development of haemorrhoids. ${ }^{8}$ Although pathophysiology of haemorrhoids is not clearly understood, various other conditions like straining, prolonged lavatory sitting, constipation, diarrhoea and conditions associated with elevated intra-abdominal pressure have been implicated. ${ }^{9}$ Aging causes haemorrhoid progression.3,10,11 A third of patients with bleeding haemorrhoids require treatment which needs to be tailored according to grades of haemorrhoids, patient preference and expertise of procedure.12 Treatment is often divided between nonoperative management, office procedures and surgical management utilising an operating room. ${ }^{13}$ Broadly, grade 1 and 2 haemorrhoids are treated with non-operative treatment in the form of dietary modification, injection sclerotherapy, rubber band ligation, endoscopic band ligation, electro-coagulation or infrared coagulation. ${ }^{12,8}$ Primary goal of all forms of therapy is to achieve fibrosis and obliteration of bleeding vessel. Injection sclerotherapy is one of the most commonly practiced, easily available forms of non-surgical treatment in adults. ${ }^{14}$ We have studied the role of sclerotherapy in the management of symptomatic first and second degree haemorrhoids. Sclerotherapy is gold standard in 1st degree pile treatment. ${ }^{15}$ Similar to rubber band ligation, injection sclerotherapy may also be undertaken in the outpatient setting. ${ }^{16}$ Injection sclerotherapy is preferable to current coagulation for the outpatient treatment of haemorrhoids because it is quicker, less tedious and a more comfortable procedure with equally effective early results. ${ }^{16}$ Sclerotherapy for haemorrhoids is a less-invasive, lesspainful procedure that causes the problematic haemorrhoid to shrivel and dissipate within a short period of time. ${ }^{17} \mathrm{~A}$ long spinal needle is used via anoscope. Induration is the indicator of proper depth. ${ }^{18}$ The most common sclerosing agent used is $5 \%$ Phenol in Almond oil, which is mainly effective for haemorrhage. ${ }^{19}$ Other agents include Phenol in Arachis oil, Polidocanol, Quinine and Urethane, Aetoxisclerol, Xiao Zhi Ling (XZL) (Consisting of Chinese nutgalls and Aluminium Potassium Sulphate), OC 108 and 50\% Dextrose. Sclerosing agent blocks vessels and causes inflammation and fibrosis that fixes haemorrhoid to the surrounding tissue, preventing prolapse. ${ }^{20}$ Sclerotherapy has the least complications among other haemorrhoid treatments, which prevents the progression of the disease. ${ }^{3,21}$ Complications with sclerosants are rare but include local infections, prostatitis, portal pyaemia, and erectile dysfunction.22 Urological complications are due to anteriorly misplaced injections in the substance of prostate/urethra or periprostatic venous plexus. ${ }^{23}$ So it is not recommended to use sclerotherapy in anterior haemorrhoids. ${ }^{23}$ Other complications include allergic reactions, psychogenic reactions (Collapse, vasovagal shock), infection, incontinence, prostatic abscess and very rarely retroperitoneal sepsis, necrotising fasciitis of rectum and lifethreatening sepsis.24,25 Serious complications from sclerotherapy are rare, they occur only in $0.02 \%$ or 1 in 5000 injections and arise mostly from improper technique. ${ }^{26}$ Our 
study shows safety and effectiveness of sclerotherapy in management of first and second degree of haemorrhoids very well.

\section{SUMMARY AND CONCLUSION}

Results of this present study concludes that the sclerotherapy is an easy, safe, well tolerated, cheap and effective modality for treatment of first and second degree of internal haemorrhoids, which can be performed on OPD basis.

\section{LIMITATIONS}

As the study was applied only on a small group of patients, so results may not reflect the scenario worldwide.

\section{ACKNOWLEDGMENT}

We are very much thankful to Prof. Dr. G. P. Shrivastava, Ex H.O.D., Department of Surgery, Govt. Shyam Shah Medical College and associated Sanjay Gandhi Memorial Hospital, Rewa, Madhya Pradesh, India, for providing us the opportunity to study the cases and also encouraging us to report the study.

\section{REFERENCES}

1. Sneider EB, Maykel A. Diagnosis and management of symptomatic hemorrhoids. Surg Clin North Am 2010;90(1):17-32.

2. Appalaneni V, Fanelli RD, Sharaf RN, et al. The role of endoscopy in patients with anorectal disorders. Gastrointest Endosc 2010;72(6):1117-23.

3. Sklow B. Benign anorectal conditions. Clin Colon Rectal Surg 2007;20(2):77-85.

4. Chen, Herbert. Illustrative handbook of general surgery. Berlin: Springer 2010:217.

5. Acheson AG, Scholefield JH. Management of hemorrhoids. BMJ 2008;336(7640):380-3.

6. Chauhan VF. Prospective comparative study of sclerotherapy by hypertonic saline and absolute alcohol for the treatment of hemorrhoids. Gujrat Medical Journal 2014;69(1):82-86.

7. Santos G, Novell JR, Khoury G, et al. Long term results of large dose, single session phenol injection sclerotherapy for hemorrhoids. Dis Colon Rectum 1993;36(10):958-61.

8. Lohsiriwat V. Hemorrhoids: from basic pathophysiology to clinical management. World J Gastroenterol 2012;18(17):2009-17.

9. Staford SJ, Klein MD. Hemorrhoids. In: Kleigman RM, Stanton BF, St. Geme JW, et al, eds. Nelson textbook of pediatrics. 19th edn. New Delhi, India: Elsevier 2012:1360-61.

10. Schwarts SI. Principles of surgery. $8^{\text {th }}$ edn. New York: McGraw-Hill 2010:1383-93.

11. Ponsky JL, Mellinger JD, Simon IB. Endoscopic retrograde hemorrhoidal sclerotherapy using $23.4 \%$ saline: a preliminary report. Gastrointest Endosc 1991;37(2):155-8.
12. Nijhawan $S$, Udawat $H$, Gupta $G$, et al. Flexible video endoscopic injection sclerotherapy for second and third degree internal hemorrhoids. Journal of Digestive Endoscopy 2011;2(1):1-5.

13. Kaidar-Person O, Person B, Wexner SD. Hemorrhoidal disease: a comprehensive review. Journal of the American College of Surgeons 2007;204(1):102-17.

14. Aggarwal B, Gupta S. Effectiveness of retrograde endoscopic sclerotherapy (REST) for first and second degree internal hemorrhoids in children. IJRRMS 2013;3(4):18-20.

15. Singh MP, Bhargava R, Ranwaka $R$, et al. Prospective study on different modalities of treatment for symptomatic haemorrhoids. Journal of Evolution of Medical and Dental Sciences 2014;3(26):7127-31.

16. Varma JS, Chung SC, Li AK. Prospective randomised comparison of current coagulation and injection sclerotherapy for the outpatient treatment of haemorrhoids. Int J Colorectal Dis 1991;6(1):42-5.

17. Chugh A, Singh R, Agrawal PN. Management of hemorrhoids. Indian $\mathrm{J}$ of Clinical Practice 2014;25(6):577-80.

18. Quijano CE, Abalos E. Conservative management of symptomatic and/or complicated haemorrhoids in pregnancy and the puerperium. Cochrane Database of Syst Rev 2005;3:CD004077.

19. MacRae HM, McLeod RS. Comparison of hemorrhoidal treatment modalities. A meta-analysis. Diseases of the Colon \& Rectum1995;38(7):687-94.

20. Alatiso OI, Arigbabu OA, Lawal 00, et al. Endoscopic hemorrhoidal sclerotherapy using 50\% dextrose water: a preliminary report. Indian J Gastroenterol 2009;28(1):31-2.

21. Johanson JF, Sonnenberg A. The prevalence of hemorrhoids and chronic constipation. An epidemiologic study. Gastroenterology 1990;98(2):380-6.

22. Konsten J, Baeten CG. Hemorrhoidectomy Vs Lord's method: 17-year follow-up of a prospective randomized trial. Dis Colon Rectum 2000;43(4):503-6.

23. Al-GhnaniemR, LeatherAJ, RennieJA. Survey of methods of treatment of hemorrhoids and complications of injection sclerotherapy. Ann $\mathrm{R}$ Coll Surg Engl 2001;83(5):325-8.

24. Kaman L, Aggrawal S, Kumar R, et al. Necrotizing fasciitis after injection sclerotherapy for hemorrhoids. Dis Colon Rectum 1999;42(3):419-20.

25. Barwell J, Watkins RM, Llyod-Davies E, et al. Life threatening retroperitoneal sepsis after hemorrhoidal injection sclerotherapy: Report of a case. Dis Colon Rectum 1999;42(3):421-3.

26. Bayer I, Myslovaty B, Picovsky BM. Rubber band ligation of hemorrhoids. Convenient and economic treatment. J Clin Gastroenetrol 1996;23(1):50-2. 